\title{
Enhanced bioremoval of refractory compounds from dyeing wastewater using optimized sequential anaerobic/aerobic process
}

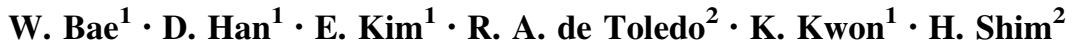

Received: 20 November 2015/Revised: 18 March 2016/ Accepted: 12 April 2016/Published online: 25 April 2016

(C) Islamic Azad University (IAU) 2016

\begin{abstract}
The upflow anaerobic sludge blanket process followed by the biological aerated filter process was employed to improve the removal of color and recalcitrant compounds from real dyeing wastewater. The highest removal efficiency for color was observed in the anaerobic process, at 8-h hydraulic retention time, seeded with the sludge granule. In the subsequent aerobic process packed with the microbe-immobilized polyethylene glycol media, the removal efficiency for chemical oxygen demand increased significantly to $75 \%$, regardless of the empty bed contact time. The average influent non-biodegradable soluble chemical oxygen demand was $517 \mathrm{mg} / \mathrm{L}$, and the average concentration in effluent from the anaerobic reactor was $363 \mathrm{mg} / \mathrm{L}$, suggesting the removal of some recalcitrant matters together with the degradable ones. The average nonbiodegradable soluble chemical oxygen demand in effluent from the aerobic reactor was 87,93 , and $118 \mathrm{mg} / \mathrm{L}$, with the removal efficiency of 76,74 , and $67 \%$, at 24-, 12-, and 8-h empty bed contact time, respectively. The combined anaerobic sludge blanket and aerobic cell-entrapped process was effective to remove the refractory compounds from real dyeing wastewater as well as in reducing organic loading to meet the effluent discharge limits. This integrated process is considered an effective and economical treatment technology for dyeing wastewater.
\end{abstract}

\section{H. Shim}

hjshim@umac.mo

1 Department of Civil and Environmental Engineering, Hanyang University, Sa 1-Dong, Ansan, Gyunggi-Do 425-791, Korea

2 Department of Civil and Environmental Engineering, Faculty of Science and Technology, University of Macau, Avenida da Universidade, Taipa, Macau SAR, China
Keywords Biological aerated filter - Color removal . Microbial immobilization - Recalcitrant compounds removal · Upflow anaerobic sludge blanket

\section{Introduction}

Due to the growth of dyeing industries and the development of various textiles, dyestuffs, and dyeing processes, a significant amount of refractory compounds such as surfactants, polyvinyl alcohol (PVA), ethylene glycol (EG), and dyestuffs are released into the environment. The greater part of dyes, which can be toxic or mutagenic, in dyeing wastewater is poorly removed by the conventional wastewater treatment system (Lin and Lin 1993; Frijters et al. 2006). Different types of technologies have been developed to remove these refractory compounds. Physical and chemical treatment systems such as coagulation/sedimentation, Fenton oxidation, and ozone oxidation suffer from some drawbacks, including the requirement of intensive energy and supplementary chemicals, the high cost, and the formation of hazardous by-products (Hong et al. 2013; Fan et al. 2014). Biological treatment, in comparison, may be a good alternative due to the lower operational cost compared to most physicochemical technologies and the eco-friendly features (Popli and Patel 2015), despite such shortcomings as sludge bulking and low treatment efficiency for refractory compounds (Ahn et al. 1999). Li and Zhao (1997) reported that biological processes applied in the treatment of textile wastewater showed a practical limit in terms of the removal of organics, color, and other biodegradable substances in different activated sludge processes, with the elimination efficiencies of $90 \%$ for biochemical oxygen demand (BOD), 40-50\% for chemical oxygen demand (COD), and 
20-30 \% for color. A sequential anaerobic/aerobic treatment was developed to treat the cotton textile mill wastewater using an upflow anaerobic sludge blanket (UASB) followed by a continuously stirred tank reactor (CSTR) (Isik and Sponza 2004). The COD and color removal efficiencies of 40-85 and 39-81\% were reported, respectively, in real and artificially colored wastewaters at a total hydraulic retention time (HRT) of 5.75 days. The combination of physicochemical and biological treatment processes was also considered (Sudarjanto et al. 2006; Lucas et al. 2007; Lotito et al. 2014), but it was still not easy to meet the discharge limit for color. Zou (2015) recently developed a hybrid method combining ozonation, activated carbon, and biological aerated filter (BAF) for the advanced treatment of dyeing wastewater for reuse, despite the high cost for ozonation. In comparison, the biological approaches to treat dyeing wastewater were reported successful by employing anaerobic/aerobic (Brown and Hamburger 1987; Shaw et al. 2002; Amaral et al. 2014), facultative anaerobic ( $\mathrm{Li}$ and $\mathrm{Xi} 2004$ ), and anaerobic (Senthilkumar et al. 2011) processes to remove aromatic amines formed from the azo-bond dyestuff. The aerobic sludge granules highly concentrated with microorganisms (Kolekar et al. 2012), the redox mediator (Rios-Del Toro et al. 2013), and the PVA immobilization media (Chen et al. 2003) had been applied for the removal of color from dyeing wastewater. The degradation of PVA contained in dyeing wastewater by pure or mixed microorganisms had also been reported (Kim et al. 1997; Choi et al. 2004). To improve the efficiency of dyestuff biodegradation, such microbial immobilization technologies using polyvinylidene fluoride (Al-Zuhair and El-Nass 2011), PVA (Takei et al. 2011), alginate (Chen et al. 2010), and polyethylene glycol (PEG) (Kim et al. 2013) have been receiving considerable attention.

The main objective of current study was to evaluate the sequential anaerobic/aerobic process for its potential to effectively remove recalcitrant contaminants from real dyeing wastewater. The applied combined process consisted of the UASB reactor seeded with the sludge granule followed by the BAF filled with microbes-immobilized PEG media. This would be the first time the sequential UASB/BAF with cell-immobilized PEG media was used to treat real dyeing wastewater. The optimal operational factors for this combined process were also investigated to further improve the removal efficiency for color. This study was carried out at Department of Civil and Environmental Engineering, Hanyang University, Republic of Korea, during the period between 2013 and 2014.

\section{Materials and methods}

\section{Reactor setup and operational conditions}

The UASB reactor (working volume, $10 \mathrm{~L}$ ) was made of a tapered acrylic cylinder and the inside water temperature was maintained at $30{ }^{\circ} \mathrm{C}$ using a water jacket (Fig. 1). The reactor was seeded with the sludge granule dominated by mesophilic microorganisms, obtained from the anaerobic wastewater treatment facility at a brewery industry located in Choongchungbuk-Do, Korea (Fig. 2a). Eighty percent of the reactor volume was filled with the sludge granule, and the biomass concentration was maintained at approximately 35,000 mg volatile suspended solids (VSS)/L. The BAF reactor consisted of a $2.0 \mathrm{~m}$ high acrylic cylinder (inner diameter, $0.10 \mathrm{~m}$ ) and was filled with the cell-entrapped PEG media (packing, $75 \%$ ). A steel sieve was installed at both upper and lower parts of the reactor to prevent the media washout. The BAF was operated in an upflow feeding mode using a peristaltic pump (Masterflex, USA) at the empty bed contact time (EBCT) of $8 \mathrm{~h}$. Backwashing was performed using a diaphragm pump (backwashing flow rate, $5 \mathrm{~L} / \mathrm{min}$ ). The dissolved oxygen (DO) concentration inside reactor was above $3 \mathrm{mg} / \mathrm{L}$ (air flow rate, $0.5 \mathrm{~L} / \mathrm{min}$ ). The vessel used to feed dyeing wastewater into reactor was maintained at $4{ }^{\circ} \mathrm{C}$ using a cooler to reduce the microbial contamination.

\section{Characteristics of dyeing wastewater}

The dyeing wastewater used was obtained from the equalizer after the screening followed by the $\mathrm{pH}$ adjustment at a dyeing wastewater treatment plant in Ansan, Korea. The characteristics of dyeing wastewater were as follows: plant design treatment capacity, $100,000 \mathrm{~m}^{3} /$ day; influent $\mathrm{pH}, 7.5 \pm 0.5$; oxidation reduction potential (ORP), $60 \pm 28 \mathrm{mV}$; total chemical oxygen demand (TCOD), $869 \pm 67 \mathrm{mg} / \mathrm{L}$; soluble COD (SCOD), $720 \pm 68 \mathrm{mg} / \mathrm{L}$; total biochemical oxygen demand (TBOD), $286 \pm 59 \mathrm{mg} / \mathrm{L}$; soluble BOD (SBOD), $216 \pm 44 \mathrm{mg} / \mathrm{L}$; and color, $1288 \pm 196$ ADMI (American Dye Manufacturers Institute) units.

\section{Microbial immobilization}

Microorganisms capable of degrading refractory compounds, isolated from the above mentioned dyeing wastewater treatment plant, were first suspended in a PEG solution containing additive (inorganic compound), crosslinker (D-sorbitol), and promotor $\left(N, N, N, N^{\prime}\right.$-tetramethylethylenediamine), and mixed thoroughly with an 
Fig. 1 Schematic of the sequential anaerobic/aerobic reactor process

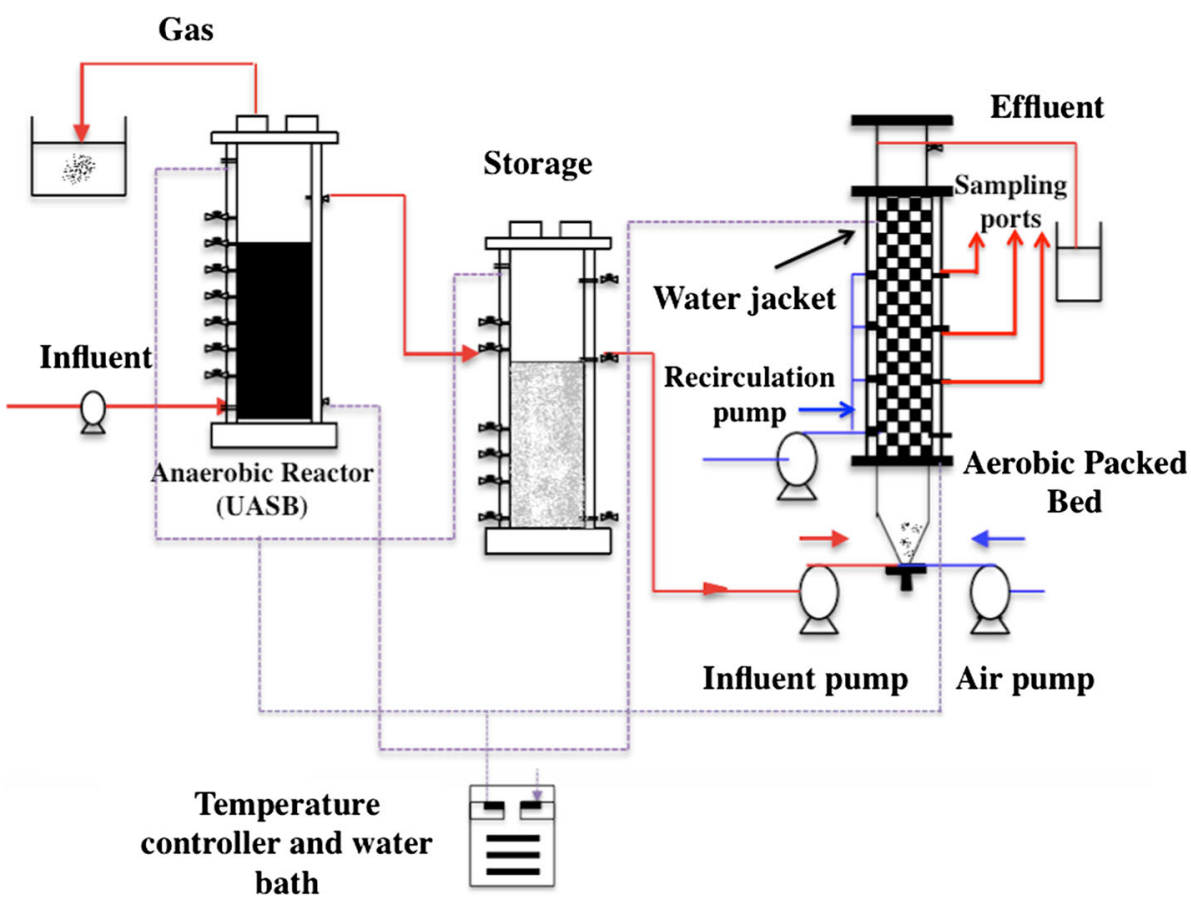

b)

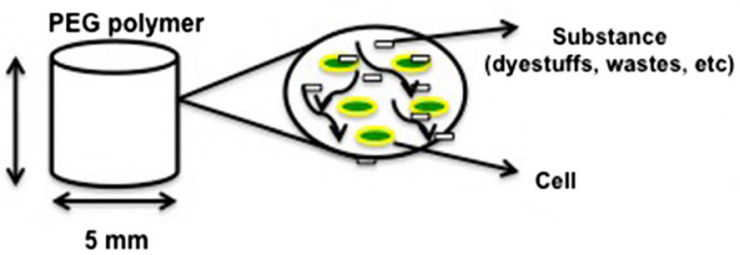

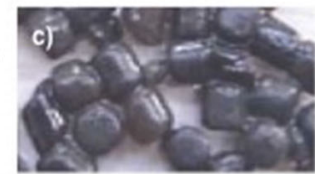

a)

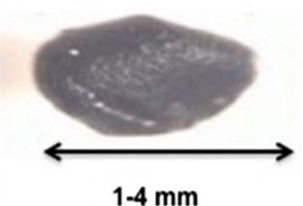

$5 \mathrm{~mm}$

Fig. 2 Pictures of $\mathbf{a}$ anaerobic sludge granule $(\times 100)$, b concept of cell-immobilized media, and $\mathbf{c}$ cell-immobilized media

initiator (potassium persulfate). The composition of immobilizing materials was $18 \%$ (w/v) PEG prepolymer, $40 \%$ (w/v) additive, $0.9 \%(\mathrm{w} / \mathrm{v})$ cross-linker, $0.5 \%(\mathrm{w} / \mathrm{v})$ promoter, $0.25 \%(\mathrm{w} / \mathrm{v})$ initiator, and $5 \%(\mathrm{w} / \mathrm{v})$ mixed bacterial culture capable of degrading refractory compounds. The polymerization method used was a modification from Sumino et al. (1992). After the addition of initiator, the mixture was immediately passed through a polyvinyl chloride (PVC) tube (inner diameter, $4 \mathrm{~mm}$ ) and left at room temperature for about $10 \mathrm{~min}$. The subsequently obtained elastic gel containing microorganisms was extruded from the PVC tube and cut at the length of $4 \mathrm{~mm}$, producing pellets of uniform shape (porosity, $\leq 0.5 \mu \mathrm{m}$ ) (Fig. 2b). The pellets were washed thoroughly in water before use. All the chemicals used for polymerization were purchased from the Sigma-Aldrich Chemical Co. (St. Louis, MO, USA).

\section{Evaluation of color removal at different HRTs}

To investigate the effect of different hydraulic retention time (HRT: 24, 8, and $6 \mathrm{~h}$ ) on the decolorization, the dyeing wastewater was fed to the UASB reactor followed by the BAF reactor using peristaltic pumps at various flow rates. At the end of reactor operation, the cell-immobilized media in BAF were taken out to remove the biomass grown/attached on the reactor wall and settled at the reactor outlet. After washing the media, the reactor was fed with tap water to the full capacity, followed by a new operational run at another HRT. The experimental runs were operated with a decreasing HRT from 24 to $6 \mathrm{~h}$, corresponding to an increase in the loading rate. 
Evaluation of COD and color removal along the height of UASB reactor

To evaluate the effect of changes in sludge granule at different reactor heights, samples were taken from four different heights (up to 2, 4, 6, and $8 \mathrm{~L}$ working volume from the reactor bottom), and the changes in color, SCOD, $\mathrm{pH}$, and ORP were measured.

\section{Evaluation of COD and color removal at different heights and EBCTs in BAF reactor}

After the BAF reactor was operated using the effluent discharged from the preceding UASB reactor as feeding, samples were taken from four different heights (up to 20, 60,100 , and $140 \mathrm{~cm}$ from the reactor bottom) to investigate the characteristics of color and COD removals at different EBCTs $(24,12$, and $8 \mathrm{~h})$.

\section{Analysis}

Samples were first filtered through a glass-fiber filter (Whatman, GF/C). BOD, COD, $\mathrm{NH}_{4}^{+}-\mathrm{N}, \mathrm{NO}_{2}{ }^{-}-\mathrm{N}$, $\mathrm{NO}_{3}{ }^{-}-\mathrm{N}$, total phosphorus (TP), SS (suspended solids), and color were measured following Standard Methods (APHA/AWWA/WEF 2005). The method and measurement accuracy was evaluated by blank (deionized water) and replicate analyses.

\section{Results and discussion}

\section{Effect of HRT on refractory compounds removal in UASB reactor}

Figure $3 \mathrm{a}$ shows the removal efficiency for color at different HRTs in the UASB reactor. The average effluent color was 397 ADMI at the early operational period $(\mathrm{HRT}=24 \mathrm{~h})$, with the removal efficiency of $69 \%$. Even though the HRT was reduced to $8 \mathrm{~h}$ after 20 days, the removal efficiency was still stable at $70 \%$ (effluent color at 392 ADMI). When the reactor was operated with 6-h HRT, a relatively lower average removal efficiency of $63 \%$ was obtained (effluent color at 473 ADMI). The obtained results are in accordance with Oh et al. (2004), where the UASB coupled with an activated sludge reactor was used to treat real textile wastewater (color, 500-1400 ADMI) at different HRTs $(6,12$, and $18 \mathrm{~h})$, with $65 \%$ color removal at 18-h HRT. The decolorization of recalcitrant dyes in
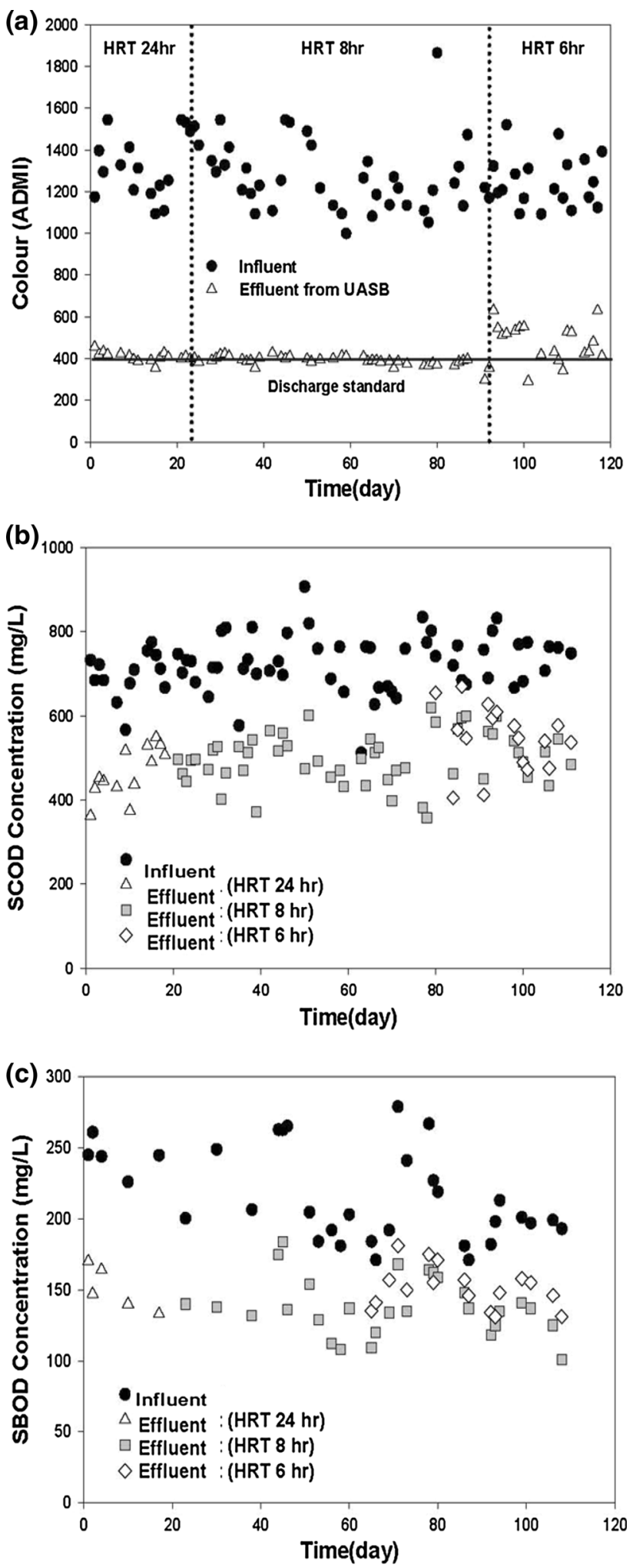

Fig. 3 Effect of HRT on a color, b SCOD, and $\mathbf{c}$ SBOD removal in the UASB reactor 
anaerobic reactors is generally a slow process, which requires long HRTs to reach a satisfactory extent of color removal ( $\mathrm{Li}$ et al. 2009). Keskinkan and Lugal Göksu (2007) also stated that the variation in HRT is an important factor in dye treatment and the treatment performance increased with the increasing HRT in their study. Rodrigues da Silva et al. (2012) also observed that a short HRT (3 h) was not sufficient to allow a higher decolorization, suggesting that a short HRT was not long enough to allow the dye reduction satisfactory. According to the legal discharge limit for color intensity in Korea (400 ADMI; Oh et al. 2004), the developed biological methodology in current study can be potentially used to treat real dyeing wastewater. On the other hand, even though the anaerobic dye reduction could be achieved using different microorganisms, no single microbial strain has been reported able to decolorize a broad range of dyes. Therefore, the use of mixed cultures such as anaerobic granular sludge would be a more rational alternative (Shah 2015).

As shown in Fig. 3b, the influent SCOD was $723 \mathrm{mg} / \mathrm{L}$ and the effluent after anaerobic treatment was $462 \mathrm{mg} / \mathrm{L}$ (36\% removal) and $492 \mathrm{mg} / \mathrm{L}$ (32\% removal) at $24-$ and 8-h HRT, respectively. In comparison, at 6-h HRT, the removal efficiency decreased significantly to $24 \%$ (547 mg/L in effluent). This lower COD removal efficiency also observed in others (Oh et al. 2004; Amaral et al. 2014) and can be associated with the presence of hardly biodegradable compounds as well as the possible toxic effects of dyestuffs and sodium chloride in real dyeing wastewater on the microbial activity. Wang et al. (2008) showed the degradation of some complicated pollutants present in printing and dyeing wastewaters was better using the UASB reactor (COD removal, $35 \%$ ) compared to the anaerobic acidogenic unit (COD removal, $4 \%$ ), at the same HRT $(15 \mathrm{~h})$. In their study, although the COD removal efficiency was only $35 \%$, the categories of alkanes were reduced by $75 \%$ and consequently the UASB reactor was proven to be effective to degrade refractory compounds, resulting in the generation of intermediates (phenol, at $31 \mu \mathrm{g} / \mathrm{L}$ ) more readily degraded in the subsequent anaerobic step. These findings are in accordance with the current study where the anaerobic unit was used as a pretreatment to improve the biodegradability of dyeing wastewater.

The removal efficiencies for SBOD were 39,36 , and $28 \%$ at the HRT of 24,8 , and $6 \mathrm{~h}$, respectively, despite the fluctuations of organic loading in influent (Fig. 3c). According to Frijters et al. (2006), it was almost impossible to quantify the dye concentrations and know its exact composition at a given time due to the diversity of organic compounds present. However, since the largest group (60-70\%) of synthetic colorants is considered azo dyes (Isik and Sponza 2006; Popli and Patel 2015), it is still possible that such chromophores as azo group $(-\mathrm{N}=\mathrm{N}-)$ can be broken down into more easily biodegradable compounds during the anaerobic step, then to be further mineralized in the subsequent aerobic step. The exact mechanism for the dye reduction, whether occurring intracellularly or extracellularly, is still a subject of investigation (Shah 2015). In the current study, after color and COD removals were compared, the 8-h HRT was found suitable for the UASB reactor to reduce the energy cost and treat a larger amount of wastewater per unit time.

\section{Removal efficiency along the UASB reactor height}

The changes in color, SCOD, $\mathrm{pH}$, and ORP at different heights in the anaerobic reactor are shown in Fig. 4. The reactor was operated at 8-h HRT, and samples were taken from four different heights (up to 2, 4, 6, and $8 \mathrm{~L}$ from the reactor bottom), representing the average HRT passed from the bottom. The removal efficiency for color was approximately $20 \%$ at the 2-h HRT location and increased continuously to $80 \%$ as the HRT increased. The ORP decreased from -260 to $-310 \mathrm{mV}$ at the highest location (corresponding to the 8-h HRT), and the redox potential is in a good agreement with the standard redox potentials for different azo dyes, generally between -430 and $-180 \mathrm{mV}$ (Dubin and Wright 1975). The SCOD levels did not change much up to the 6-h HRT height, but a higher organic removal was observed at the 8-h HRT location. This result implies that the color formers in dyestuff were broken down at the 6- to 8-h HRT locations, and the hardly biodegradable compound could be converted to the easily biodegradable ones, resulting in the higher organic removal (Panswad et al. 2001). There was no significant $\mathrm{pH}$ variation during the organics removal along the UASB reactor height.

\section{Effect of EBCT on refractory compounds removal in $\mathrm{BAF}$ reactor}

The BAF reactor was operated at different EBCTs (24, 12, and $8 \mathrm{~h}$ ) to investigate the optimal EBCT for the effective removal of refractory compounds from dyeing wastewater. The changes of SCOD in influent (i.e., effluent from the UASB reactor) and effluent from the BAF reactor at each EBCT are shown in Fig. 5a. After the reactor reached a 
Fig. 4 Changes in color, $\mathrm{SCOD}, \mathrm{ORP}$, and $\mathrm{pH}$ at different heights in the UASB reactor

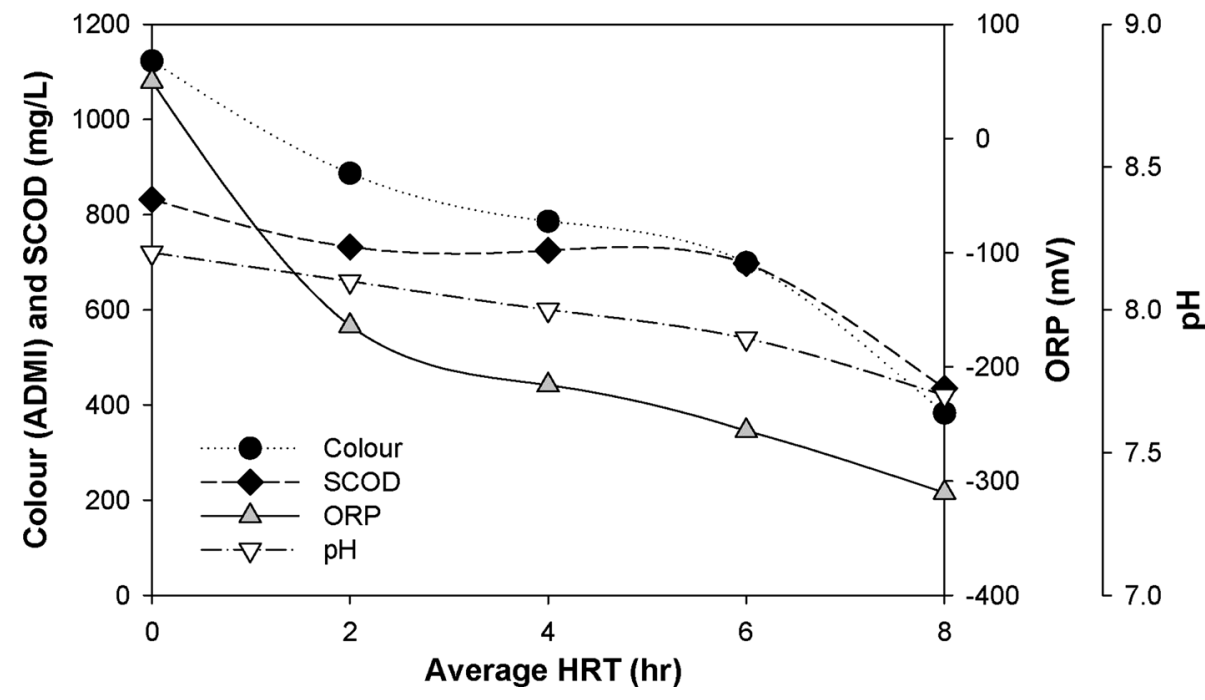

steady-state in about 20 days after the operation, the average influent SCOD concentration was $493 \mathrm{mg} / \mathrm{L}$, while the average effluent concentrations at 24- and 12-h EBCT were 85 and $88 \mathrm{mg} / \mathrm{L}$, respectively. The removal efficiencies were similar (83 and $82 \%$ ) despite the organic loading doubled. In comparison, the removal efficiency at 8-h EBCT decreased to $75 \%$. On the other hand, while the average SBOD concentration in effluent from the UASB reactor was $125 \mathrm{mg} / \mathrm{L}$, the SBOD concentration in effluent from the BAF reactor was 8,7 , and $11 \mathrm{mg} / \mathrm{L}$ at 24-, 12-, and 8-h EBCT, respectively, indicating high removal efficiencies ( $\geq 90 \%$ ) for the degradable compounds (Fig. 5b).

According to Ali et al. (2009), SS are important repositories for toxic heavy metals and dyes in the receiving water bodies, and for this reason, the impact of SS on water color was also evaluated. Figure 5c shows color and SS amounts in effluent from the BAF reactor at different EBCTs. Despite the significant fluctuations in influent, a significant amount of color was removed in the preceding UASB reactor (Fig. 3a), while just some color removal in the subsequent BAF reactor was observed. The color amount in effluent from the BAF reactor was almost constant regardless of increase or decrease of the effluent SCOD or SS concentrations. Therefore, color was considered not directly affected by the $\mathrm{SS}(\geq 1 \mu \mathrm{m})$ as well as the change of SCOD. In comparison, when the effluent from the $\mathrm{BAF}$ reactor was coagulated with $\mathrm{FeCl}_{3}$, color was further decreased to 300 ADMI, suggesting that color was more related to the colloidal particulate matters. These results are also in accordance with others (O'Neill et al. 1999; Oh et al. 2004; Hakimelahi et al. 2012) where the main reduction of dyes occurred in the anaerobic phase and the contribution of aerobic phase to decolorization was negligible. The aerobic unit enhanced the SCOD and SBOD removals and was crucial to improve the effluent water quality. Kapdan and Oztekin (2006) also observed the aerobic phase provided improvement in COD removal and acted as a polishing step after the anaerobic color removal.

\section{Removal efficiency along the $\mathrm{BAF}$ reactor height}

As shown in Fig. 6a, at $20 \mathrm{~cm}$ height from the BAF reactor bottom, $65 \%$ of total organics were removed at 24- and 12-h EBCTs, while $40 \%$ removed at 8 -h EBCT. The removal efficiencies generally increased as the EBCT increased, and $75 \%$ removal efficiencies for SCOD were achieved from the reactor height of $20 \mathrm{~cm}$, except for the 8-h EBCT. The SBOD concentration along the reactor height at the 8-h EBCT was below $10 \mathrm{mg} / \mathrm{L}$ from the $20 \mathrm{~cm}$ reactor height (Fig. 6b). Therefore, the removal of degradable organic compounds mainly occurred as soon as influent (effluent from the UASB reactor) was added to the $\mathrm{BAF}$ reactor.

\section{Evaluation of removal potential for phosphorus and nitrogen}

The average TP concentration in effluent from the BAF reactor was $4 \mathrm{mg} / \mathrm{L}$, while the average $\mathrm{TN}$ concentration was 28,29 , and $15 \mathrm{mg} / \mathrm{L}$ in influent, effluent from the anaerobic reactor, and effluent from the aerobic reactor, respectively. The higher $\mathrm{NH}_{4}{ }^{+}-\mathrm{N}$ concentration in effluent from the UASB reactor was probably due to the biological reduction of chromophores groups $(-\mathrm{N}=\mathrm{N}-)$ generating 

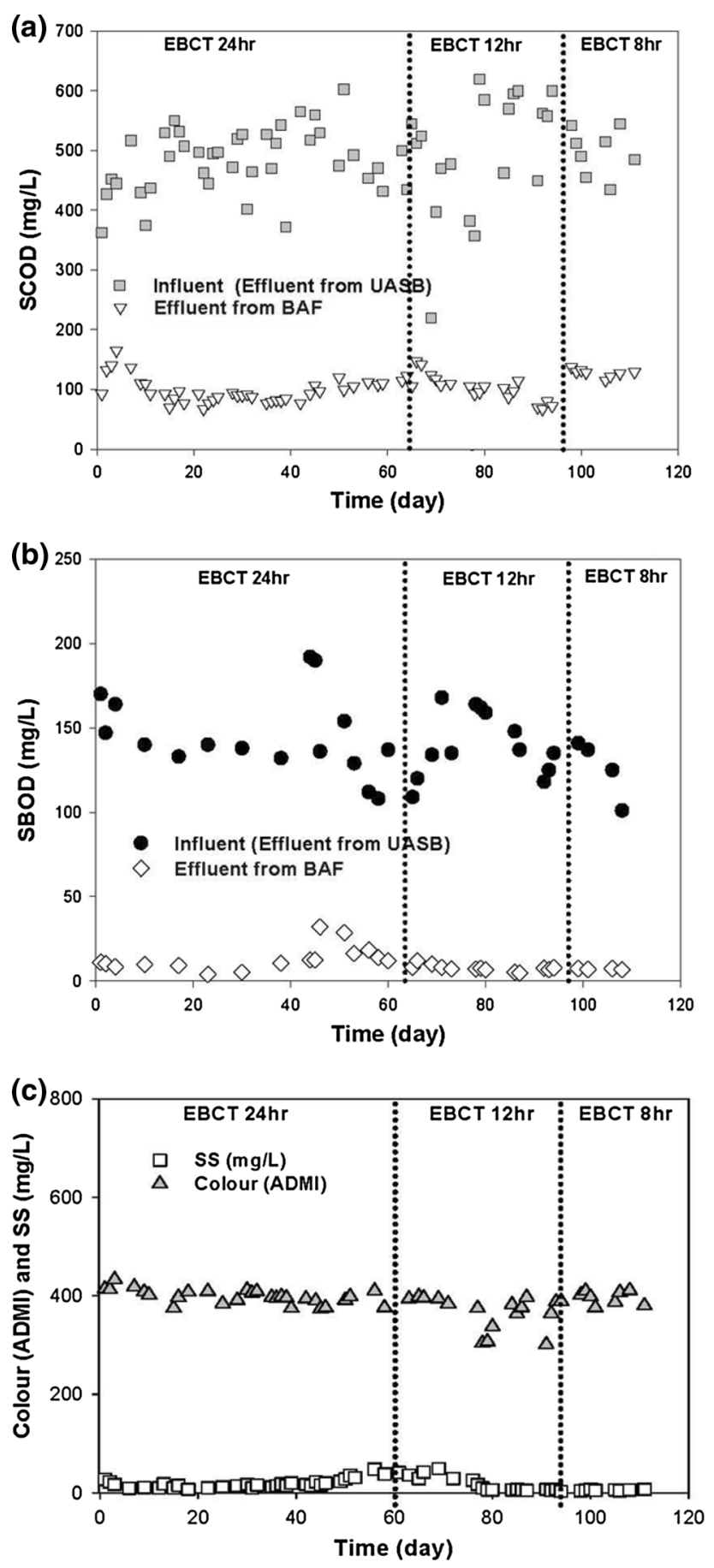

Fig. 5 Effect of EBCT on a SCOD, b SBOD, and c color and SS removal in the BAF reactor

aromatic amines as most $\mathrm{NH}_{4}^{+}-\mathrm{N}$ was measured as $\mathrm{TN}$. The $\mathrm{NO}_{3}{ }^{-}-\mathrm{N}$ concentration, on the other hand, was about $10 \mathrm{mg} / \mathrm{L}$ in influent, while it was not detected in effluent from the UASB reactor but was about $7.5 \mathrm{mg} / \mathrm{L}$ in effluent (a)

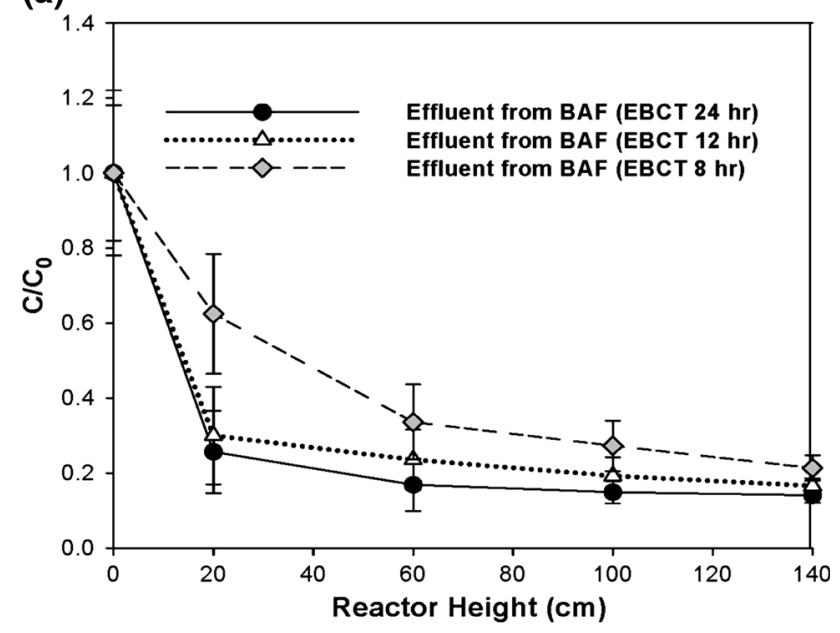

(b)

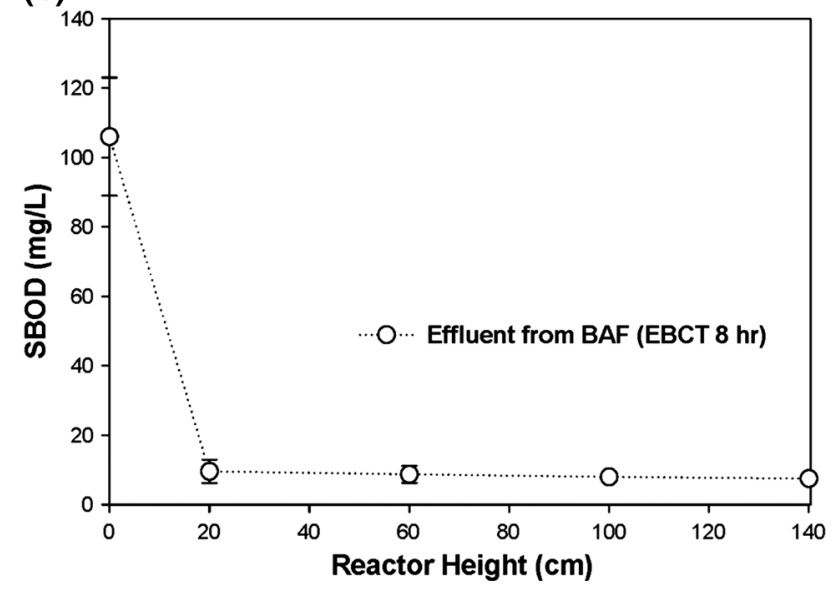

Fig. 6 Removal of a SCOD and $\mathbf{b}$ SBOD at different heights in the $\mathrm{BAF}$ reactor

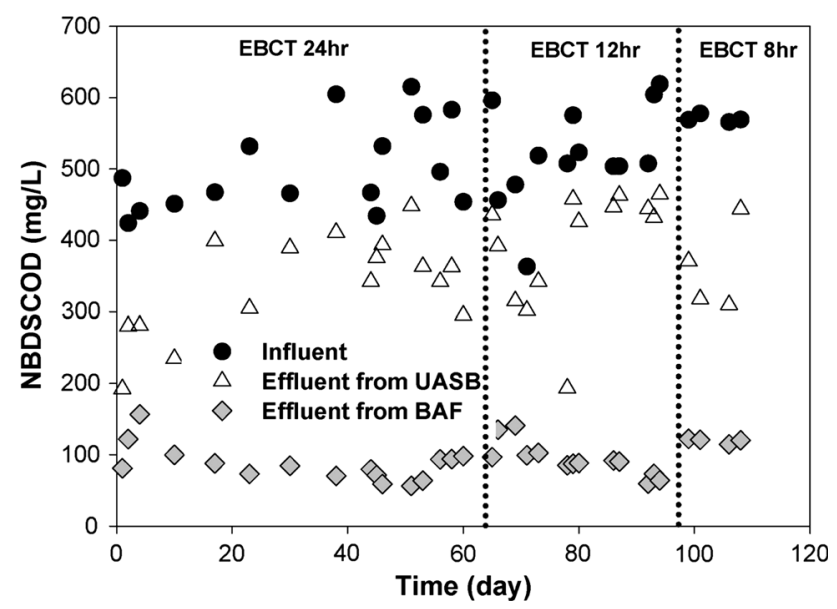

Fig. 7 Effect of EBCT on non-biodegradable (NBD) SCOD concentrations in the sequential anaerobic/aerobic reactor 
from the BAF reactor, further implying the occurrence of nitrification in the aerobic process.

\section{Behavior of non-biodegradable SCOD}

In order to evaluate the removal efficiency for recalcitrant matters, the non-biodegradable (NBD) SCOD was measured for influent, effluent from the UASB reactor, and effluent from the BAF reactor, at different EBCTs, and the results are shown in Fig. 7. The NBDSCOD was calculated as soluble ultimate BOD $\left(\mathrm{SBOD}_{\mathrm{u}}\right)$ subtracted from SCOD, and the $\mathrm{SBOD}_{\mathrm{u}}$ value was assumed 1.5 times of SBOD. The average influent NBDSCOD concentration was $517 \mathrm{mg} / \mathrm{L}$ and the average concentration in effluent from the anaerobic reactor operated at 8 -h HRT was $363 \mathrm{mg} / \mathrm{L}$, suggesting the removal of some recalcitrant matters together with degradable matters. The average NBDSCOD concentration in effluent from the aerobic reactor was 87,93 , and $118 \mathrm{mg} /$ L, with the removal efficiency of 76,74 , and $67 \%$, at 24-, 12-, and 8-h EBCT, respectively (Fig. 7). Despite the loading of recalcitrant matters gradually increased as the EBCT decreased, the aerobic reactor still showed a high removal efficiency ( $\geq 65 \%$ ) for the NBDSCOD, regardless of the EBCT applied, and this was considered due to the superior effect of media immobilized with microorganisms in degrading recalcitrant matters present in dyeing wastewater. Compared to the suspended microbial technology, cell immobilization shows many advantages such as high biomass, high metabolic activity, and strong resistance to toxic chemicals, and could be cost effective since the immobilized microbes can be used several times without significant loss of activity (Martins et al. 2013). The immobilization and maintenance of high concentration of biomass are main factors that improve the bacterial tolerance to the toxic substances present in dyeing wastewater (Pagga and Brown 1986). In the current study, the immobilized microbes were essential to successfully reduce COD and toxicity of the UASB effluent. The developed sequential anaerobic/aerobic treatment system can be effective in decolorizing textile wastewater as well as in reducing organic loading to meet the effluent discharge limits due to its cost effective and environmentally friendly nature.

\section{Conclusion}

The anaerobic UASB process seeded with the sludge granule, followed by the aerobic BAF process packed with the cell-immobilized PEG media in sequence was employed to treat real dyeing wastewater and the removal efficiencies for refractory compounds were evaluated. The optimal HRT for the stable color removal in the UASB reactor was $8 \mathrm{~h}$ and the highest color removal occurred at the 6-h HRT location corresponding to the respective reactor height. The removal efficiencies for SCOD and $\mathrm{SBOD}$ in the $\mathrm{BAF}$ reactor was $\geq 75 \%$, occurred at the lower part of reactor, regardless of EBCTs. The refractory compounds present in dyeing wastewater could be effectively removed using the sequential continuous anaerobic/ aerobic process. Most color was removed during the anaerobic process, while refractory compounds were effectively removed during the aerobic process. The UASB/BAF filled with cell-immobilized PEG media was used for the first time to treat real dyeing wastewater and showed the high removal efficiency for non-biodegradable SCOD. This integrated anaerobic/aerobic reactor process is considered an effective and feasible treatment technology for dyeing wastewater.

Acknowledgments This research was supported by the University of Macau Multi-Year Research Grants, MYRG204(Y3-L4)-FST11SHJ and MYRG2014-00112-FST, and a grant from the Macau Science and Technology Development Fund (FDCT/061/2013/A2 and FDCT/063/2013/A2).

\section{Compliance with ethical standards}

Conflict of interest The authors declare that they have no conflict of interest.

\section{References}

Ahn DH, Chang WS, Yoon TI (1999) Dyestuff wastewater treatment using chemical oxidation, physical adsorption and fixed bed biofilm process. Process Biochem 34:429-439

Ali N, Hammed A, Ahmed S (2009) Physicochemical characterization and bioremediation perspective of textile effluent, dyes and metals by indigenous bacteria. J Hazard Mater 164:322-328

Al-Zuhair S, El-Naas M (2011) Immobilization of Pseudomonas putida in PVA gel particles for the biodegradation of phenol at high concentrations. Biochem Eng J 56:46-50

Amaral FM, Kato MT, Florêncio L, Gavazza S (2014) Color, organic matter and sulfate removal from textile effluents by anaerobic and aerobic processes. Bioresour Technol 163:369-384

APHA, AWWA, WEF (2005) Standard methods for the examination of water and wastewater. American Public Health Association/ American Water Works Association/Water Environment Federation, Washington DC

Brown D, Hamburger B (1987) The degradation of dyestuffs: Part III-investigations of their ultimate degradability. Chemosphere 16:1539-1553

Chen KC, Wu JY, Huang CC, Liang YM, Hwang J (2003) Decolorization of azo dye using PVA-immobilized microorganisms. J Biotechnol 101:241-252 
Chen CY, Chen SC, Fingas M, Kao CM (2010) Biodegradation of propionitrile by Klebsiella oxytoca immobilized in alginate and cellulose triacetate gel. J Hazard Mater 177:856-863

Choi K, Park C, Kim S, Lyoo W, Lee SH, Lee J (2004) Polyvinyl alcohol degradation by Microbacterium barkeri KCCM 10507 and Paenibacillus amylolyticus KCCM 10508 in dyeing wastewater. J Microbiol Biotechnol 14:1009-1013

Dubin P, Wright KL (1975) Reduction of azo food dyes in cultures of Proteus vulgaris. Xenobiotica 5:563-571

Fan J, Li H, Shuang C, Li W, Li A (2014) Dissolved organic matter removal using magnetic anion exchange resin treatment on biological effluent of textile dyeing wastewater. J Environ Sci 26:1567-1574

Frijters CTMJ, Vos RH, Scheffer G, Mulder R (2006) Decolorizing and detoxifying textile wastewater, containing both soluble and insoluble dyes, in a full scale combined anaerobic/aerobic system. Water Res 40:1249-1257

Hakimelahi M, Moghaddam MRA, Hashemi SH (2012) Biological treatment of wastewater containing an azo dye using mixed culture in alternating anaerobic/aerobic sequencing batch reactors. Biotechnol Bioprocess Eng 17:875-880

Hong JM, Jiang JS, Chang CT, Chen BY (2013) Comparative isocline analysis upon microbial decolorization in immobilized cell bioreactor using biocarriers. Bioresour Technol 145:313-320

Isik M, Sponza DT (2004) Anaerobic/aerobic sequential treatment of a cotton textile mill wastewater. J Chem Technol Biotechnol 79:1268-1274

Isik M, Sponza DT (2006) Biological treatment of acid dyeing wastewater using a sequential anaerobic/aerobic reactor system. Enzyme Microbial Technol 38:887-892

Kapdan IK, Oztekin R (2006) The effect of hydraulic residence time and initial COD concentration on color and COD removal performance of the anaerobic-aerobic SBR system. J Hazard Mater 136:896-901

Keskinkan O, Lugal Göksu MZ (2007) Assessment of the dye removal capability of submersed aquatic plants in a laboratoryscale wetland system using Anova. Braz J Chem Eng 24:193-202

Kim CG, Choi YJ, Lee CW, Lim YT, Ryu JG (1997) Removal of PVA from dyeing wastewater by polyvinyl alcohol-degrading symbiotic microorganism. Kor J Appl Microbiol Biotechnol 25:89-95

Kim M, Han D, Cui F, Bae W (2013) Recalcitrant organic matter removal from textile wastewater by an aerobic cell immobilized pellet column. Water Sci Technol 67:2124-2131

Kolekar YM, Nemade HN, Markad VL, Adav SS, Patole MS, Kodam KM (2012) Decolorization and biodegradation of azo dye, reactive blue 59 by aerobic granules. Bioresour Technol 104:818-822

Li Y, Xi DL (2004) Decolorization and biodegradation of dye wastewaters by a facultative-aerobic process. Environ Sci Pollut Res 11:372-377

Li XZ, Zhao YG (1997) On-site treatment of dyeing wastewater by a bio-photoreactor system. Water Sci Technol 36:165-172

Li L, Zhou J, Wang J, Yang F, Jin C, Zhang G (2009) Anaerobic biotransformation of azo dye using polypyrrole/anthraquinone disulphonate modified active carbon felt as a novel immobilized redox mediator. Sep Purif Technol 66:375-382

Lin SH, Lin CM (1993) Treatment of textile waste effluents by ozonation and chemical. Water Res 27:1743-1748
Lotito AM, De Sanctis M, Rossetti S, Lopez A, Di Iaconi C (2014) On-site treatment of textile yarn dyeing effluents using an integrated biological-chemical oxidation process. Int J Environ Sci Technol 11:623-632

Lucas MS, Dias AA, Sampaio A, Amaral C, Peres JA (2007) Degradation of a textile reactive azo dye by a combined chemical-biological process: Fenton's reagent-yeast. Water Res 41:1103-1109

Martins SCS, Martins CM, Fiúza LMCG, Santaella ST (2013) Immobilization of microbial cells: a promising tool for treatment of toxic pollutants in industrial wastewater. Afr $\mathrm{J}$ Biotechnol $12: 4412-4418$

O'Neill C, Hawkes FR, Esteves SRR, Hawkes DL, Wilcox SJ (1999) Anaerobic and aerobic treatment of a simulated textile effluent. J Chem Technol Biotechnol 74:993-999

Oh YK, Kim YJ, Ahn Y, Song SK, Park S (2004) Color removal of real textile wastewater by sequential anaerobic and aerobic reactors. Biotechnol Bioprocess Eng 9:419-422

Pagga U, Brown D (1986) The degradation of dyestuffs: Part II. Behaviour of dyestuffs in aerobic biodegradation tests. Chemosphere 15:479-491

Panswad T, Iamsamer K, Anotai J (2001) Decolorization of azoreactive dye by polyphosphate- and glycogen-accumulating organisms in an anaerobic-aerobic sequencing batch reactor. Bioresour Technol 76:151-159

Popli S, Patel UD (2015) Destruction of azo dyes by anaerobicaerobic sequential biological treatment: a review. Int J Environ Sci Technol 12:405-420

Rios-Del Toro EE, Celis LB, Cervantes FJ, Rangel-Mendez JR (2013) Enhanced microbial decolorization of methyl red with oxidized carbon fiber as redox mediator. J Hazard Mater 260:967-974

Rodrigues da Silva ME, Firmino PIM, Santos AB (2012) Impact of the redox mediator sodium anthraquinone-2,6-disulphonate (AQDS) on the reductive decolourisation of the azo dye Reactive Red 2 (RR2) in one- and two-stage anaerobic systems. Bioresour Technol 121:1-7

Senthilkumar M, Gnanapragasam G, Arutchelvan V, Nagarajann S (2011) Influence of hydraulic retention time in a two-phase upflow anaerobic sludge blanket reactor treating textile dyeing effluent using sago effluent as the co-substrate. Environ Sci Pollut Res 18:649-654

Shah MP (2015) Microbe-mediated degradation of synthetic dyes in wastewater. In: Singh SN (ed) Microbial degradation of synthetic dyes in wastewaters. Springer International Publishing, Switzerland, pp 205-241

Shaw CB, Carliell CM, Wheatley AD (2002) Anaerobic/aerobic treatment of coloured textile effluents using sequencing batch reactors. Water Res 36:1993-2001

Sudarjanto G, Keller-Lehmann B, Keller J (2006) Optimization of integrated chemical-biological degradation of a reactive azo dye using response surface methodology. J Hazard Mater 138:160-168

Sumino T, Nakamura H, Mori N, Kawagychi Y (1992) Immobilization of nitrifying bacteria by polyethylene glycol prepolymer. J Ferment Bioeng 73:37-42

Takei T, Ikeda K, Ijima H, Kawakami K (2011) Fabrication of poly(vinyl alcohol) hydrogel beads crosslinked using sodium sulfate for microorganism immobilization. Process Biochem 400:1051-1060 
Wang J, Long MC, Zhang ZJ, Chi LN, Qiao XL, Zhu HX, Zhang ZF (2008) Removal of organic compounds during treating printing and dyeing wastewater of different process units. Chemosphere 71:195-202
Zou XL (2015) Combination of ozonation, activated carbon, and biological aerated filter for advanced treatment of dyeing wastewater for reuse. Environ Sci Pollut Res 22:8174-8181 